See discussions, stats, and author profiles for this publication at: https:/ www.researchgate.net/publication/2257 14876

\title{
The Caucasian corticioid fungi: Level of endemism, similarity, and possible contribution to European fungal diversity
}

Article in Fungal Diversity · January 2011

DOI: 10.1007/51 3225-011-0122-0

\section{CITATIONS}

9

4 authors:

Masoomeh Ghobad-Nejhad

Iranian Research Organization for Science and Technology

61 PUBLICATIONS 2,033 CITATIONS

SEE PROFILE

Jaakko Hywonen

University of Helsinki

233 PUBLICATIONS 3,220 CITATIONS

SEE PROFILE

\section{READS}

327

Nils Hallenberg

University of Gothenburg

130 PUBLICATIONS 2,902 CITATIONS

SEE PROFILE

Eugene Yurchenko

Bialystok University of Technology

41 PUBLICATIONS 403 CITATIONS

SEE PROFILE

Some of the authors of this publication are also working on these related projects:

Diversity of corticioid fungi in East Asia View project

Project Polyporoid fungi of Belarus View project 


\title{
The Caucasian corticioid fungi: level of endemism, similarity, and possible contribution to European fungal diversity
}

\author{
Masoomeh Ghobad-Nejhad • Nils Hallenberg • \\ Jaakko Hyvönen • Eugene Yurchenko
}

Received: 26 April 2011/Accepted: 7 July 2011/Published online: 30 July 2011

(C) Kevin D. Hyde 2011

\begin{abstract}
We assess the composition of corticioid fungi in the Caucasus region for the first time. The Caucasian corticioids were compared with those of well-documented areas in the Northern Hemisphere using the Tripartite similarity index and cluster analysis. To investigate the significance of the Caucasus region as a possible contributor to the colonization of wood-inhabiting basidiomycetes in Europe, DNA sequences of nuclear ribosomal internal transcribed spacers (ITS1 and ITS2) belonging to the corticioid fungus Peniophorella praetermissa were analysed for comparisons of genetic diversity within and differentiation between geographical regions. Putative species endemism and disjunction of corticioids in the Caucasus region is also discussed. The composition of corticioid fungi in the Caucasus region was found to be
\end{abstract}

Electronic supplementary material The online version of this article (doi:10.1007/s13225-011-0122-0) contains supplementary material, which is available to authorized users.

\footnotetext{
M. Ghobad-Nejhad ( $₫)$

Botanical Museum, University of Helsinki,

P.O. Box 7, FI-00014 Helsinki, Finland

e-mail: ghobadnejhad@myco-lich.com

N. Hallenberg

Department of Plant and Environmental Sciences,

Gothenburg University,

Box 461, S-405 30 Gothenburg, Sweden

M. Ghobad-Nejhad · J. Hyvönen

Plant Biology, University of Helsinki,

P.O. Box 65, FI-00014 Helsinki, Finland

E. Yurchenko

V.F. Kuprevich Institute of Experimental Botany,

Akademichnaya 27,

BY-220072 Minsk, Belarus
}

distinctly more similar to Europe and North America than to East Asia and India. Similarity tests and molecular Fsts both point to a strong connection between the Caucasus and Europe. The highest molecular diversity in P. praetermissa was in the Caucasus and East Asia as compared with other regions studied. The Caucasus and East Asia were significantly differentiated from each other, and unlike Caucasian samples, East Asian sequences were highly divergent from the European ones. This result suggests that the Caucasus might have been a source of colonization for Europe. Endemism is very low, possibly a common feature for wood-inhabiting saprotrophic fungi.

Keywords Basidiomycota - Checklists - Genetic diversity Glacial refugia - Saprotrophic wood-inhabiting basidiomycetes . Tripartite similarity index

\section{Introduction}

Due to the repeated Pleistocene glaciations, the biota in many parts of the Northern Hemisphere diminished or drastically changed. The present temperate forest vegetation in the Northern Hemisphere was mostly in the form of interrupted and sparse forest cover, steppes, tundra or otherwise under ice only 20,000 years ago during the Last Glacial Maximum (LGM; Ray and Adams 2001; Svenning et al. 2008). However, the severe cold periods were interrupted by more favourable climatic conditions that enabled biota to reclaim the areas without ice-cover (Huntley and Webb 1988). Based on pollen records, it can be concluded that vegetation within the same area differed between different interglacial periods (Cheddadi et al. 2005), which emphasizes the importance of 'source' areas and refugia in development of the biota in the areas devoid 
of vegetation. Such relict areas are found today with vegetation that has persisted since the time of the LGM (Taberlet et al. 1998; Tarasov et al. 2000; Milne 2006), and a few of them are in the Caucasus region (Tarasov et al. 2000; Tumajanov 1971; see Suppl. Fig. 1).

The Caucasus region is one of the hotspots of biodiversity (Myers et al. 2000), with considerable species richness as well as a high number of endemic, rare and threatened species (Krever et al. 2001). The region is categorized among the IUCN's recognized centres of plant diversity and endemism (Davis et al. 1995). With its western Palearctic glacial refugia, collectively known as Colchis and Hyrcan (Tumajanov 1971; Volodicheva 2002), the region has been shown as a contributor to the European recolonization of biota after retreat of glaciers, documented through recent palynological and phylogeographical studies (e.g., Tarasov et al. 2000; Brunhoff et al. 2003; Atkinson et al. 2006; Randi 2006; Kotlík et al. 2008). The fungal composition of the Caucasus has, however, largely escaped empirical scrutiny. Our study seeks to address the connections between the corticioid fungi of the Caucasus region with that of Europe, compared with North America, East Asia, and India (see Suppl. Table 1). The corticioid fungi are a group of predominantly saprotrophic basidiomycetes with simple and mostly effused fruiting body configurations and colonizing dead wood. According to the recent studies by MG and colleagues on Caucasian wood fungi (GhobadNejhad et al. 2009; Ghobad-Nejhad 2011), some 380 species of corticioids are known to occur in the region. In this study, we also investigate the possible contribution of the region to the present mycota of Europe, by analysing the genetic diversity within and between populations of the widespread corticioid species Peniophorella praetermissa (P. Karst.) K.H. Larss. (Hymenochaetales, Basidiomycota), based on samples from different parts of its range. Finally, putative species endemism and disjunction of corticioids in the Caucasus region are discussed.

\section{Materials and methods}

Checklist analysis We compared corticioid fungi of the Caucasus region with those of Europe (northern, easterncentral, and southern or Mediterranean), North America (western, eastern), East Asia, and India, based on the availability of updated and reliable species lists. Similarity between the corticioid species of the Caucasus and the areas listed above was addressed by employing a Tripartite similarity index (Tulloss 1997; Tulloss and Tulloss 2004). This index (T) takes into account not only the number of entries common between two lists, but also the number of entries in one list that are not present in the other list (see Tulloss 1997). To increase sensitivity to several aspects of input data, $T$ employs cost functions into its three elements $\mathrm{U}, \mathrm{S}$, and $\mathrm{R}$ which are calculated as the following:

$$
\begin{aligned}
& U=\frac{\log \left(1+\frac{\min (b, c)+a}{\max (b, c)+a}\right)}{\log 2} \\
& S=\sqrt{\frac{\log 2}{\log \left(2+\frac{\min (b, c)}{a+1}\right)}} \\
& R=\frac{\log \left(1+\frac{a}{a+b}\right) \cdot \log \left(1+\frac{a}{a+c}\right)}{(\log 2)^{2}}
\end{aligned}
$$

where $a$ is the number of entries common to both lists, $b$ is the number of entries in the first list that are not in the second, and $c$ is the number of entries in the second list that are not in the first. $U$ corrects for the difference in the size of the two lists being compared. $S$ provides a penalty for the difference between the size of $a$ and the smaller of the two lists being compared. $R$ takes into account whether $a$ covers a fraction (percentage) of one list that is different from that of the other list (see Tulloss 1997). The T is obtained by multiplying the three cost functions:

$T=U \times S \times R$

The value of $\mathrm{T}$ ranges from 0 to 1 , where 0 indicates no elements in common while 1 indicates that the two lists are identical (Tulloss 2005).

We calculated the $\mathrm{T}$ index for the three largest corticioid genera in the Caucasus region, i.e. Hyphodontia, Phlebia, and Peniophora (see Ghobad-Nejhad et al. 2009). These genera represent different ecological guilds, inhabiting dry branches and twigs in exposed habitats, or decayed wood in humid habitats (Suppl. Table 2). The occurrence of these genera in the Caucasus region was compared with their presence in the areas as defined above. To check if $T$ values would differ by checklist size, similarity between the total corticioids of the Caucasus and the total corticioids of the above mentioned areas was also calculated using the $\mathrm{T}$ index. The species data come from well-edited checklists surveyed or assembled from available publications (Suppl. Table 1) or received from specialists, and the specimens examined by us. Available publications include Akulov et al. (2003); Andreasen and Hallenberg (2009); Bernicchia and Gorjón (2010); Breitenbach and Kränzlin (1986); Dai (2010); Dai et al. (2004); Dämon (2001); Denchev and Assyov (2010); Ginns and Lefebvre (1993); Hansen and Knudsen (1997); Hjortstam and Ryvarden (1984); Hjortstam et al. (1998); Kotiranta et al. (2009); Langer (1994); Lee and Jung (2005, 2006); Lee et al. (2002); Legon et al. (2005); Lim et al. (2005); Maurer et al. (2009); Natarajan and Kolandavelu (1998); Parmasto (1986); Rattan (1977); Ryvarden (2010); 
Ryvarden et al. (2003); Yurchenko (2010), and some other sources pointed out in Suppl. Table 1. The size of the checklist compiled for each area is shown in Suppl. Table 3 (lists available from the corresponding author).

An agglomerative hierarchical cluster analysis was performed for each genus and for total corticioids to further deduce the similarity of the Caucasus to the seven geographical locations mentioned above, using $\mathrm{R}$ v. 2.8.1 (R Development Core Team 2008) with the Euclidean metric and compact method. UPGMA dendrograms were computed with the Jaccard coefficient, and bootstrap branch supports were calculated using WinBoot (Yap and Nelson 1996) with 1,000 replicates. Bootstrap support values were superimposed on the tree obtained in R.

Genetic diversity Haplotype analysis was performed for the widespread corticioid species Peniophorella praetermissa. The nuclear ribosomal internal transcribed spacer (ITS1, 5.8S, ITS2) dataset by Hallenberg et al. (2007) was modified and supplemented with new sequences (Table 1), and the final dataset consisted of 66 sequences from 10 locations (populations): Caucasus (CAU, 10 samples), East Asia (EAS, 8 samples), eastern-central Europe (ECEU, 5 samples), northern Europe (NEU, 12 samples), Mediterranean Europe (MEU, 9 samples for ITS1, 8 samples for ITS2), Greenland (4 samples), North America (NAM, 8 samples), South America (SAM, 6 samples), Africa (AF, 1 sample), and New Zealand (NZ, 3 samples). This is one of the largest samplings of a species among corticioid fungi studied so far. Despite the potential problems with ITS (e.g., Nilsson et al. 2008), the region has been shown as a useful marker for phylogeographic studies and haplotype analyses not least in fungi (e.g., Kauserud et al. 2007b; Geml et al. 2008; Moncalvo and Buchanan 2008; Wirtz et al. 2008; Carlsen et al. 2011). Tajima's D neutrality test separately performed for both loci did not reject the neutral 'null' hypothesis, which eliminates the concerted evolution to be likely. Phylogenetic analysis by Hallenberg et al. (2007) has shown that the species complex is monophyletic and the extant cryptic species within this complex appear to have a similar ecology and substantial overlap in morphology. It is therefore reasonable to treat $P$. praetermissa as one species and the genetic divergence within this complex as a function of time. The procedure of DNA extraction, PCR and sequencing follow Ghobad-Nejhad et al. (2010). Sequences were assembled in SeqMan NGen (DNASTAR) or Sequencher $^{\mathcal{O}}$ v. 4.1 (GeneCodes, Ann Arbor, USA) and aligned in MAFFT v. 6.624b (Katoh and Toh 2008). The ITS1 and ITS2 portions were extracted from the ITS dataset, and analysed separately.

Sequences were collapsed into haplotypes using FaBox (Villesen 2007) and analysed with Arlequin v. 3.5.1.2 (Excoffier and Lischer 2010). Within and between popula- tion pairwise distances, population comparisons (Fst, 100 permutations), and molecular diversity (pi, as a measure of nucleotide diversity, i.e. the probability that two randomly chosen homologous nucleotides are different) were computed with pairwise distance method at a 0.05 significance level. To infer population differentiation $(F s t)$, the number of steps in the Markov chain was set to 100,000 and burn-in to 10,000 . A high Fst implies a considerable degree of differentiation among populations. Genetic diversity of populations was compared using the obtained values of molecular diversity (pi) in each of datasets and expected heterozygosity $(\mathrm{H})$ over polymorphic nucleotides in each of ITS1 and ITS2 regions.

\section{Results and discussion}

Similarity tests A graphical display of all the obtained T indices as well as dendrograms from cluster analysis is presented in Fig. 1. In general, $\mathrm{T}$ indices from the checklists of the three genera and the checklists of total corticioids largely agree with each other (Fig. 1a), and some conclusions can be drawn: 1) Among the regions studied here, the highest similarity of the Caucasus is to easterncentral Europe (cf. Phlebia), and the least similarity to India (cf. Hyphodontia). 2) The Caucasus is more similar to Europe and North America than to East Asia and India (see also Suppl. Table 3). Moreover, the T values between the Caucasus and Europe are significantly greater than the values between the Caucasus and North America $(p=0.05)$, with the exception of the genus Phlebia. High similarity between the Caucasus and Europe could indicate that there may have been an effective exchange of biota between them. The case with Phlebia contradicts all other analyses presented here, and therefore is difficult to explain. 3) The Caucasus is significantly more similar to East Asia than to India $(p=0.05)$ (cf. Hyphodontia). A higher similarity to Southeast Asia than to the Himalayas has been documented for European mountain plant species, apparently via a former, northerly deciduous forest belt (Zhang et al. 2007). Dendrograms from cluster analysis (Fig. 1b) were largely congruent with $\mathrm{T}$ diagrams in Fig. 1a. [See Suppl. Table 3 for Tripartite similarity values obtained from comparisons of total corticioids of the Caucasus, Europe, eastern N America, western N America, East Asia, and India].

Mueller et al. (2001) used the Simpson similarity index to deduce the biogeographical relationships between North American and Chinese macrofungi, and Núñez and Stokland (2000) used the Dice index to infer the biogeographical affinities of East Asian polypores with those of other north temperate areas. It must be noted that these indices simply apply the number of entries common to two lists and do not consider the number of entries differing between the 
Table 1 Haplotypes, isolates, and ITS GenBank accession numbers for Peniophorella praetermissa. Haplotypes of ITS 1 are shown by numerical numbers $(1,2,3, \ldots)$, haplotypes of ITS 2 are shown by letters $(\mathrm{a}, \mathrm{b}, \mathrm{c}, \ldots)$. Accession numbers starting with HQ were generated in this study (accession numbers AY618668 and AY781256 downloaded from GenBank had no isolate name, so the accession number is used directly for isolate name in the list of haplotypes). Haplotype numbers in bold contain more than one sequence and their isolates are shown with different colours to mark different locations: Caucasus (light green), East Asia (orange), northern Europe (light blue), Mediterranean Europe (dark green), Greenland (dark blue), North America (light purple), South America (dark purple), and New Zealand (brown). Isolates from Africa and eastern-central Europe appeared in singletons, i.e. haplotypes consisting of one sequence only. Singletons are not colour-marked. Isolates from Iran and Turkey refer to the collections from Caucasian parts of these countries (see GhobadNejhad et al. 2009)

\begin{tabular}{|c|c|c|c|c|c|c|}
\hline \multicolumn{2}{|c|}{ ITS1 (222 bp) } & \multicolumn{2}{|c|}{ ITS2 (218 bp) } & \multicolumn{3}{|c|}{ GenBank } \\
\hline Haplotype & Isolate & Haplotype & Isolate & Isolate & Origin & $\begin{array}{c}\text { Accession } \\
\text { number }\end{array}$ \\
\hline 1 & FP110337 & a & FP110337 & FP110337 & $\begin{array}{l}\text { USA } \\
\text { (Mississippi) }\end{array}$ & GQ409533 \\
\hline 2 & FCUG 1358 & $\mathrm{~b}$ & FCUG 1358 & FCUG 1358 & Sweden & DQ647441 \\
\hline 3 & $\begin{array}{l}\text { FCUG 1831, FCUG } \\
1874, \text { AY781256, } \\
\text { FCUG } 1708\end{array}$ & c & FCUG 1831 & $\begin{array}{l}\text { FCUG } 1831 \\
\text { FCUG } 1874 \\
- \\
\text { FCUG } 1708\end{array}$ & $\begin{array}{l}\text { Spain } \\
\text { Spain } \\
\text { Sweden } \\
\text { Finland }\end{array}$ & $\begin{array}{l}\text { DQ647446 } \\
\text { DQ647445 } \\
\text { AY781256 } \\
\text { DQ647444 }\end{array}$ \\
\hline 4 & GEL 2182 & d & $\begin{array}{l}\text { FCUG 1874, } \\
\text { AY781256 }\end{array}$ & GEL 2182 & Norway & DQ647442 \\
\hline 5 & FCUG 1828 & e & GEL 2182 & FCUG 1828 & France & DQ647443 \\
\hline 6 & TMC 34061 & f & FCUG 1708 & TMTC 34061 & Japan & DQ647452 \\
\hline 7 & $\begin{array}{l}\text { FCUG 461, FCUG } \\
900\end{array}$ & g & FCUG 1828 & $\begin{array}{l}\text { FCUG } 461 \\
\text { FCUG } 900\end{array}$ & $\begin{array}{l}\text { Norway } \\
\text { Denmark }\end{array}$ & $\begin{array}{l}\text { DQ647450 } \\
\text { DQ647451 }\end{array}$ \\
\hline 8 & FCUG 465 & $\mathrm{~b}$ & TMIC 34061 & FCUG 465 & $\begin{array}{l}\text { Canada } \\
\text { (BC) }\end{array}$ & DQ647448 \\
\hline 9 & CanadaBC493 & $\mathrm{i}$ & FCUG 461 & FCUG 493 & $\begin{array}{l}\text { Canada } \\
\text { (BC) }\end{array}$ & DQ647449 \\
\hline 10 & CanadaBC646 & j & FCUG 900 & FCUG 646 & $\begin{array}{l}\text { Canadn } \\
\text { (BC) }\end{array}$ & DQ647447 \\
\hline 11 & AY618668 & $\mathbf{k}$ & FCUG 465 & - & $\begin{array}{l}\text { Canada } \\
\text { (BC) }\end{array}$ & AY618668 \\
\hline 12 & HHB 9446 & 1 & FCUG 493 & HHB 9446 & $\begin{array}{l}\text { USA } \\
\text { (Florida) }\end{array}$ & GQ409534 \\
\hline 13 & FCUG 3190 & m & FCUG 646 & FCUG 3190 & Iran & HQ392620 \\
\hline 14 & FCUG 939 & $\mathrm{n}$ & AY618668 & FCUG 939 & Scotland & DQ647464 \\
\hline 15 & FCUG 1052 & 0 & HHB 9446 & FCUG 1052 & Romania & DQ647465 \\
\hline 16 & FCUG 2429 & $\mathrm{p}$ & FCUG 3190 & FCUG 2429 & $\begin{array}{l}\text { Russia } \\
\text { (Krasnodar) }\end{array}$ & DQ647466 \\
\hline 17 & FCUG 1804 & $q$ & FCUG 939 & FCUG 1804 & Spain & DQ647467 \\
\hline 18 & $\begin{array}{l}\text { FCUG } 1799 \\
\text { FCUG } 2375\end{array}$ & T & FCUG 1052 & $\begin{array}{l}\text { FCUG } 1799 \\
\text { FCUG } 2375\end{array}$ & Spain & DQ647454 \\
\hline \multirow[t]{3}{*}{19} & FCUG 277 , FCUG & $\mathbf{s}$ & FCUG 2429, FCUG & FCUG 277 & Denmark & DQ647453 \\
\hline & $\begin{array}{l}\text { 3200, FCUG 3031, } \\
\text { FCUG 2376, FCUG } \\
962\end{array}$ & & 1804 & $\begin{array}{l}\text { FCUG } 3200 \\
\text { FCUG } 3031\end{array}$ & $\begin{array}{l}\text { Iran } \\
\text { Canada } \\
\text { (Quebec) }\end{array}$ & $\begin{array}{l}\text { HQ392618 } \\
\text { DQ647463 }\end{array}$ \\
\hline & & & & $\begin{array}{l}\text { FCUG } 2376 \\
\text { FCUG } 962\end{array}$ & $\begin{array}{l}\text { Greenland } \\
\text { Scotland }\end{array}$ & $\begin{array}{l}\text { DQ647458 } \\
\text { DQ647460 }\end{array}$ \\
\hline 20 & FCUG 2232 & $t$ & FCUG 1799 & FCUG 2232 & Turkey & DQ647455 \\
\hline 21 & FCUG 2373 & $\mathrm{u}$ & FCUG 277 & FCUG 2373 & Greenland & DQ647457 \\
\hline 22 & FCUG 2371 & $\mathrm{v}$ & FCUG 2232 & FCUG 2371 & Greenland & DQ647456 \\
\hline 23 & FCUG 2130 & $\mathbf{w}$ & $\begin{array}{l}\text { FCUC } 3200, \text { FCUG } \\
2371\end{array}$ & FCUG 2130 & Tenerife & DQ647461 \\
\hline 24 & FCUG 2147 & $\mathbf{x}$ & FCUG 3031 & FCUG 2147 & Tenerife & DQ647462 \\
\hline 25 & FCUG 3208 & $\mathbf{y}$ & FCUG 2373 & FCUG 3208 & Iran & HQ392619 \\
\hline 26 & FCUG 2414 & $\mathrm{z}$ & FCUG 2376 & FCUG 2414 & $\begin{array}{l}\text { Russia } \\
\text { (Krasnodar) }\end{array}$ & DQ647469 \\
\hline 27 & FCUG 2461 & a月 & FCUG 962 & FCUG 2461 & $\begin{array}{l}\text { Russia } \\
\text { (Krasnodar) }\end{array}$ & DQ647470 \\
\hline 28 & FCUG 758 & bb & FCUG 2147 & FCUG 758 & $\begin{array}{l}\text { Canada } \\
\text { (Ontario) }\end{array}$ & DQ647471 \\
\hline 29 & FCUG 1682 & cc & FCUG 3208 & FCUG 1682 & Sweden & DQ647473 \\
\hline 30 & FCUG 950 & dd & FCUG 2375 & FCUG 950 & Swoden & DQ647472 \\
\hline 31 & MG125 & $e$ & FCUG 2414 & MG125 & Estonia & HQ392623 \\
\hline 32 & MG123 & ff & FCUG 2461 & MG123 & Estonia & HQ392621 \\
\hline 33 & MG124 & $\mathrm{gg}$ & FCUG 758 & MG124 & Germany & HQ392622 \\
\hline 34 & FCUG 2160 & hh & FCUG 1682 & FCUG 2160 & Gomera & DQ647474 \\
\hline 35 & TMIC 33862 & ii & FCUG 950 & TMIC 33862 & Japan & DQ647476 \\
\hline 36 & Wu 9506-27 & ii & MG125 & Wu 9506-27 & Taiwan & DQ647493 \\
\hline 37 & FCUG 3094 & kk & MG123 & FCUG 3094 & Tasmania & GQ409532 \\
\hline 38 & FCUG 2966 & 11 & MG124 & FCUG 2966 & $\begin{array}{l}\text { New } \\
\text { Zealand }\end{array}$ & DQ647480 \\
\hline \multirow[t]{4}{*}{39} & FCUG 2500, FCUG & $\mathrm{nn}$ & FCUG 2160 & FCUG 2500 & Argentina & DQ647488 \\
\hline & 2512, FCUG 2514, & & & FCUG 2512 & Argentina & DQ647489 \\
\hline & FCUG 2531 & & & FCUG 2514 & Argentina & DQ647490 \\
\hline & & & & FCUG 2531 & Argentina & DQ647491 \\
\hline 40 & FCUG 2495 & oo & TMIC 33862 & FCUG 2495 & Argentina & DQ647492 \\
\hline 41 & FCUG 824 & $\mathrm{pp}$ & Wu 9506-27 & FCUG 824 & Denmark & DQ647479 \\
\hline \multirow[t]{2}{*}{42} & $\begin{array}{l}\text { FCUG } 2165 \text {, FCUG } \\
2493\end{array}$ & q9 & $\begin{array}{l}\text { FCUG 3094, FCUG } \\
\text { 2966, FCUG } 2967 \text {, } \\
\text { FCUG 2500, FCUG }\end{array}$ & FCUG 2165 & Tenerife & DQ647485 \\
\hline & & & $\begin{array}{l}\text { 2512, FCUG 2514, } \\
\text { FCUG 2531, 7CUG } \\
\text { 2247, FCUG 2430, } \\
\text { FCUG 2218, TMIC } \\
32107\end{array}$ & FCUG 2493 & Argentina & DQ647486 \\
\hline 43 & FCUG 2967 & $\mathbf{r r}$ & $\begin{array}{l}\text { FCUG 2495, FCUG } \\
2165, \text { FCUG } 2493\end{array}$ & FCUG 2967 & $\begin{array}{l}\text { New } \\
\text { Zealand }\end{array}$ & DQ647487 \\
\hline \multirow[t]{2}{*}{44} & FCUG 22 47 , FCUG & ss & FCUG 824 & FCUG 2247 & Turkey & DQ647481 \\
\hline & 2218 & & & FCUG 2218 & Turkey & DQ647483 \\
\hline 45 & FCUG 2430 & $\mathrm{tt}$ & Wu 0104-3 & FCUG 2430 & $\begin{array}{l}\text { Russia } \\
\text { (Krasnodar) }\end{array}$ & DQ647482 \\
\hline 46 & TMIC 32107 & uu & Wu 9610-10 & TMIC 32107 & Japan & DQ647484 \\
\hline \multirow[t]{3}{*}{47} & Wu 0104-3, Wu & $\mathbf{v v}$ & TMIC 34389 & Wu 0104-3 & Taiwan & DQ647495 \\
\hline & 9610-10, TMIC & & & Wu 9610-10 & Taiwan & DQ647494 \\
\hline & 34389 & & & TMIC 34389 & Japan & DO647496 \\
\hline 48 & Wu 0309-175 & ww & Wu 0309-175 & $\begin{array}{l}\text { Wu 0309- } \\
175\end{array}$ & China (Jilin) & DQ647497 \\
\hline 49 & MUCL32673 & $\mathbf{x x}$ & MUCL32673 & MUCL32673 & Cameroon & DQ647498 \\
\hline 50 & MG122 & yy & MG122 & MG122 & Estonia & HQ392624 \\
\hline
\end{tabular}


(a)

Hyphodontia
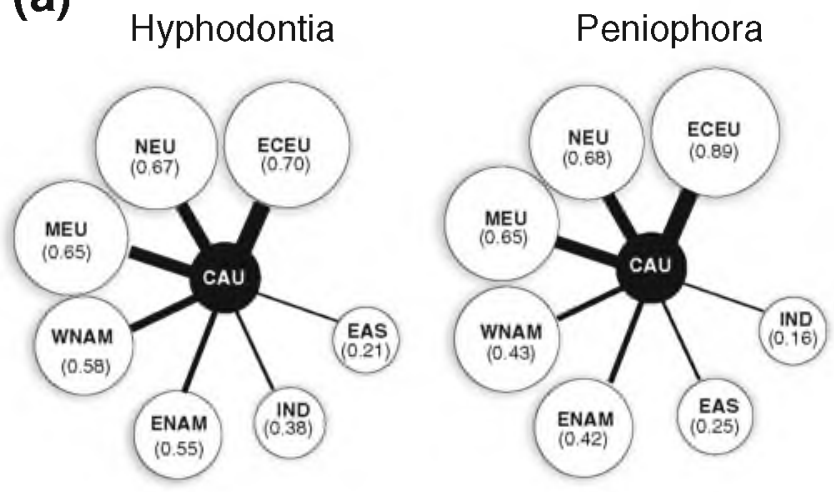

(b)

Hyphodontia $(n=73)$
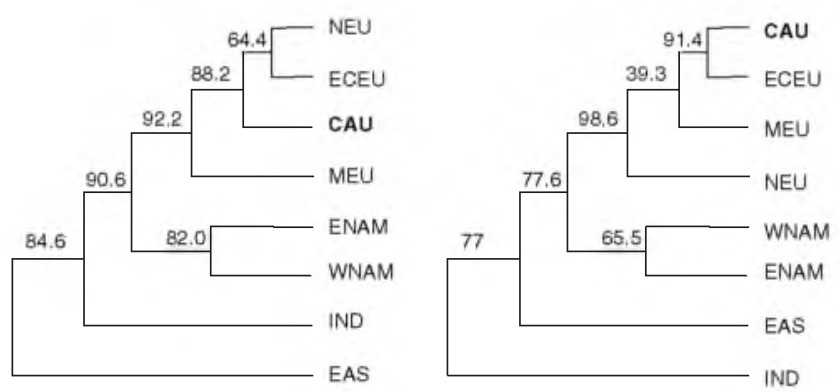

Fig. 1 a Diagrams representing the Tripartite similarity values for Hyphodontia, Peniophora, Phlebia, and for total corticioids. The size of the circles and the thickness of radia are relative to the $T$ values (numbers in brackets). b Dendrograms from cluster analysis. Numbers above branches are bootstrap support values. $n=$ the total number of

two sets being compared. They could also give misleading values when the size of the two lists differ greatly (Tulloss 1997). The percentage of corticioid species shared between the Caucasus region and other areas considered above (Simpson index, see Tulloss 1997; Tulloss and Tulloss 2004) is shown in Fig. 2. For instance, the percentage of Hyphodontia species in common between the Caucasus and northern Europe is $100 \%$. It appears that similarity can be more accurately shown by $\mathrm{T}$ values than by simply the percentage of species in common. The Tripartite similarity index has been used in several studies (e.g., Robba et al. 2005; Schils and Wilson 2006; Winemiller et al. 2008), and it has been recently modified to infer the distribution pattern of a group of taxa in a given region (Schils 2006).

We also believe that there are limitations to the use of similarity indices for assessing 'biogegraphical relationships' (see above). Indices can represent the overall similarity of biota, but not their intricate biogeographical history (Lomolino et al. 2006). Moreover, these indices do not take into account the similarities in distribution patterns (Schils 2006), nor do they take into account the importance of shared history and phylogeny of the taxa.

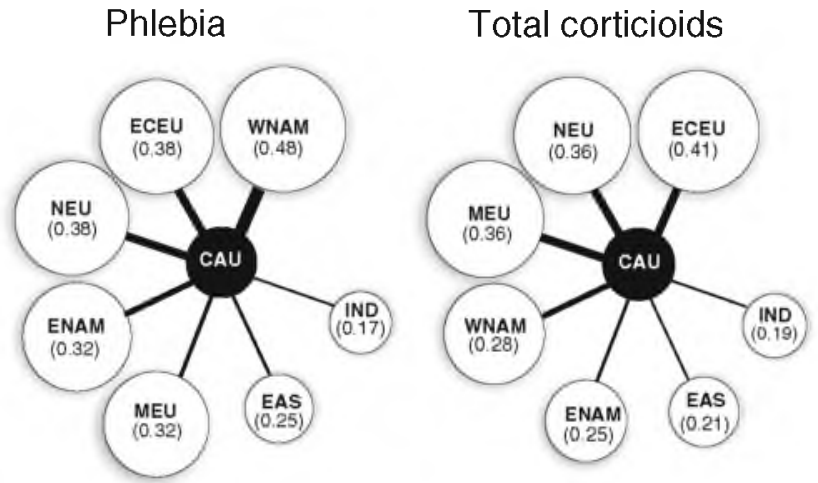

Phlebia ( $=77)$

Total corticioids $(n=1293)$
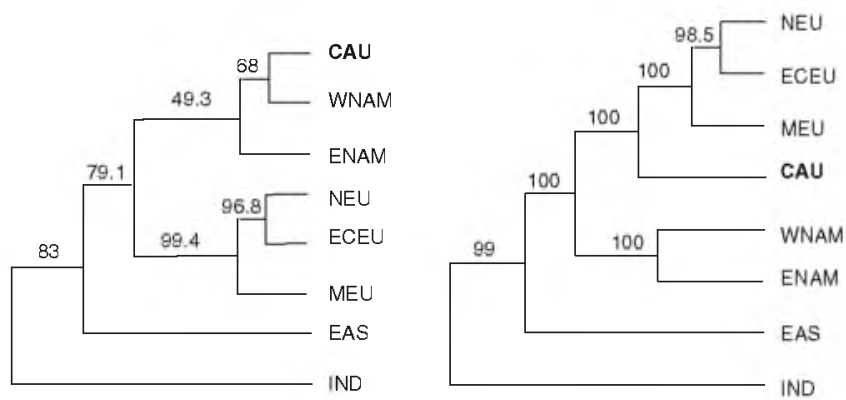

species analysed. Area abbreviations: CAU Caucasus, ECEU easterncentral Europe, $N E U$ northern Europe, $M E U$ Mediterranean Europe, ENAM eastern North America, WNAM western North America, EAS East Asia, IND India

Establishing similarity assumptions based on checklists could have some potential limitations, such as compromised reliability of input data and inconsistencies in taxonomic treatments (see Feuerer and Hawks-

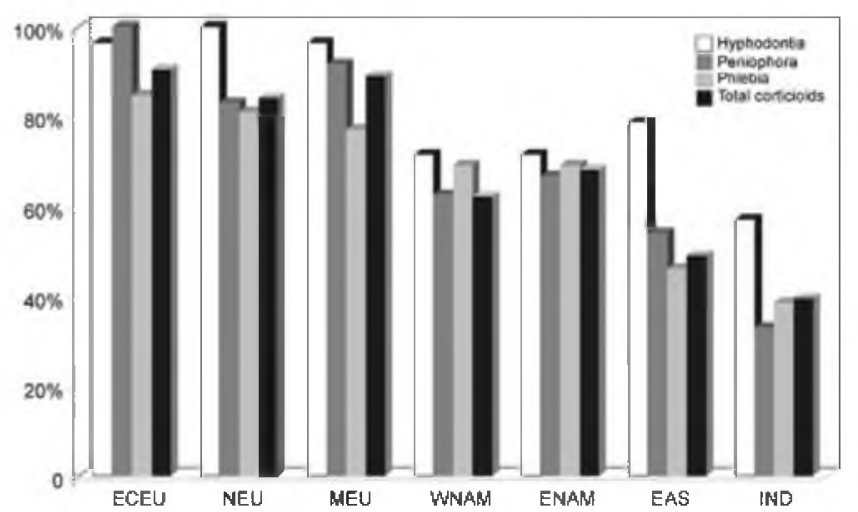

Fig. 2 The percentage of species common between the Caucasus region and other areas (Simpson index) as calculated for Hyphodontia, Peniophora, Phlebia, and for total corticioids. Area abbreviations as in Fig. 1 
worth 2007). Such concerns can, however, be satisfied to a considerable degree by avoiding poor quality data and by availability of recently revised information. For the present study, we used updated, well-edited or expertmade lists, while unreliable data were excluded. The problem with competing species interpretations as well as conflicting nomenclature and synonymy in corticioid fungi has been tackled via the open-source nomenclatural database Cortbase (Parmasto et al. 2004). It is clear that such databases not only serve taxonomy, but can also be relevant for biodiversity and biogeographical studies. All input data in our study were controlled, coordinated and adjusted prior to the analyses so that different species interpretations were avoided (see Suppl. Table 2)

Genetic diversity Sixty six sequences of ITS1 (222 bp) belonging to Peniophorella praetermissa were collapsed into 50 haplotypes (Table 1) of which 42 haplotypes were singleton while eight haplotypes contained more than one sequence. Among the shared haplotypes, one Caucasus sequence collapsed with another one from the same region in haplotype 44, and one Caucasus sequence appeared in haplotype 19 consisting of sequences from northern Europe, Greenland and North America (Quebec). The highest value of within population pairwise distance (Fig. 3a), molecular diversity, and mean expected heterozygosity (Table 2) of ITS1 was found in the Caucasus, slightly higher than East Asia, but considerably higher than other populations. Molecular diversity in the Americas, Greenland, New Zealand and Africa was significantly lower than the Caucasus/East Asia/Europe (Fig. 3a, Table 2). According to Fst calculations (Table 3, Fig. 3a), the Caucasus is significantly differentiated only from East Asia and South America, while the smallest calculated differentiation was found with northern Europe. East Asia is significantly differentiated from almost all other populations.

The ITS2 dataset consisted of 65 sequences with $218 \mathrm{bp}$, rendering 50 haplotypes (Table 1), of which five haplotypes were shared and sequences from the Caucasus incorporated into three of these: 1) haplotype s consisting of sequences from the Caucasus and Spain, 2) haplotype w including Caucasus and Greenland isolates, and 3) haplotype qq consisting of sequences from the Caucasus, Japan, New Zealand/Tasmania, and Argentina. The highest within population pairwise distance (Fig. 3b), molecular diversity, and mean expected heterozygosity for ITS2 (Table 2) was found in East Asia and. after this, in the Caucasus, the values for both being considerably higher than for other populations. As was the case with ITS1, molecular diversity of ITS2 in the Americas, Greenland,
New Zealand and Africa was significantly lower than in the Caucasus/East Asia/Europe. Sequences from East Asia showed significant $F$ st p-values for almost all other populations (Table 3), which means that they are highly differentiated and divergent (see also Fig. 3b). Caucasus sequences were significantly different only from those of East Asia, eastern-central Europe and South America, but were least differentiated from (most similar to) northernand Mediterranean Europe (Fig. 3b, Table 3).

According to the results obtained for Peniophorella praetermissa, genetic diversity and within population pairwise distances in the Caucasus region were shown to be higher than in Europe; the values are not only higher than those of northern Europe which was unforested during LGM (cf. cryptic northern refugia speculated by some studies; see e.g., Randi 2006), but also exceed those of the Mediterranean area. Since the molecular diversity of East Asian samples is also high, a Caucasian and/or an East Asian route could be postulated for the species to reach Europe (an East Asian route could be justified by the past existence of a continuous temperate forest cover in the Northern Hemisphere; see Donoghue and Smith 2004). However, both ITS regions of the East Asian samples are significantly differentiated from all other North Hemispheric populations studied here, an indication of their isolation and different history from Europe as well as from the Caucasus region. These results might indicate a possible colonization of Europe by the species from the Caucasus.

Greenland samples appear in three shared haplotypes (Table 1), i.e. with Spain (haplotype 18, ITS1), with the Caucasus/northern Europe/Quebec (haplotype 19, ITS1), and with the Caucasus (haplotype w, ITS2). Genetic diversity in Greenland isolates is lower than in Europe and North America. They are significantly different from several populations (incl. North America) but not from the Caucasus, northern Europe, and Mediterranean Europe. This may indicate that Greenland colonization has taken place at several times from different parts of Europe and the distribution has possibly extended from northern Europe to NE North America (Fig. 3; Tables 2 and 3). Molecular diversity in New Zealand and South America is very low, which can be explained by insufficient sampling in these areas or perhaps more recent colonization from the Northern Hemisphere.

The idea of a region being designated as the 'source" or 'origin of re-colonization' has most commonly been evaluated by the 'genetic diversity gradient' model, applied in numerous studies (see e.g., Taberlet et al. 1998; Hewitt 1999 and 2004; Weiss and Ferrand 2006, and several references they cite). Accordingly, the source areas are supposed to have a higher genetic diversity than the 
(a)

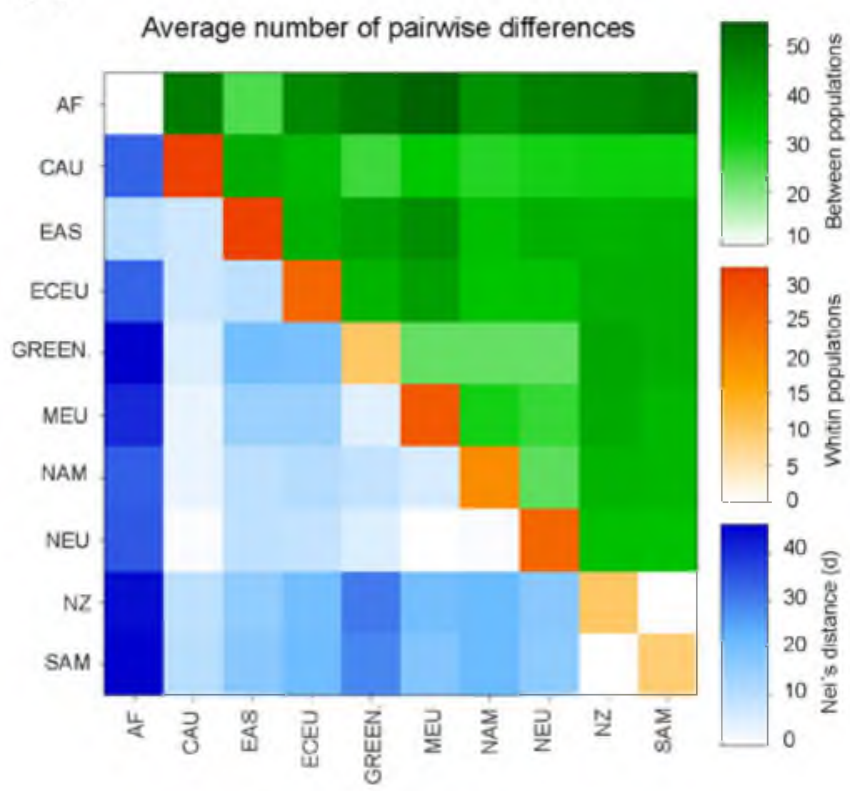

Matrix of pairwise Fst

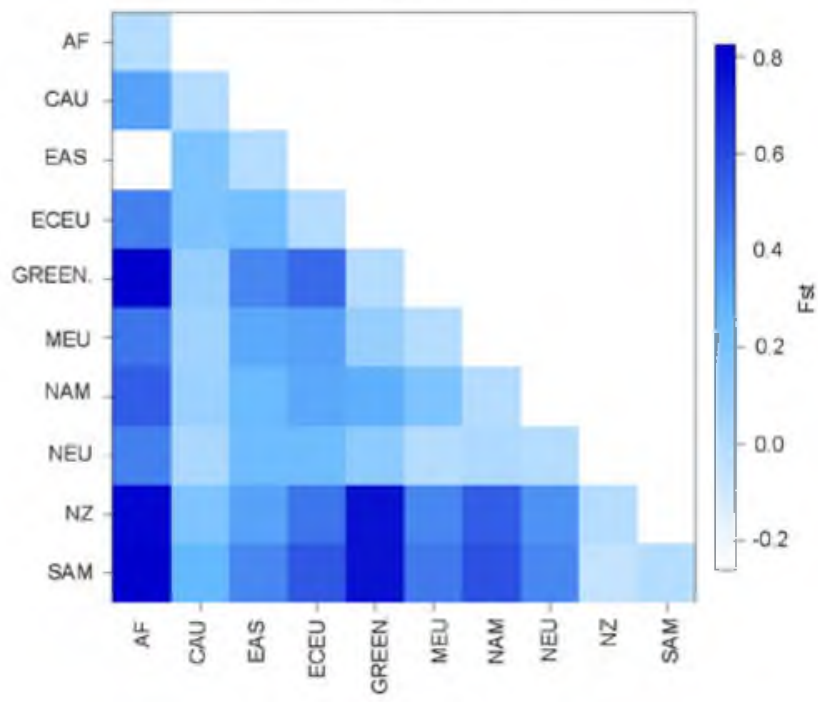

Fig. 3 Genetic diversity calculations for ITS1 (a) and ITS2 (b) in Peniophorella praetermissa from 10 locations. First row diagrams plot average number of population pairwise differences (i.e. the mean number of base-pair differences between all pairs of sequences in a samples): above diagonal shows average number of pairwise differences between populations, diagonal element indicates average

areas where the organism(s) has dispersed. Additional models are also being developed to propose much more complex scenarios having operated in nature, however. In some cases, the area with the highest diversity has been shown to have acted as a 'container', retaining a high diversity (and divergence) due to its isolation and poor biota exchange with (b)
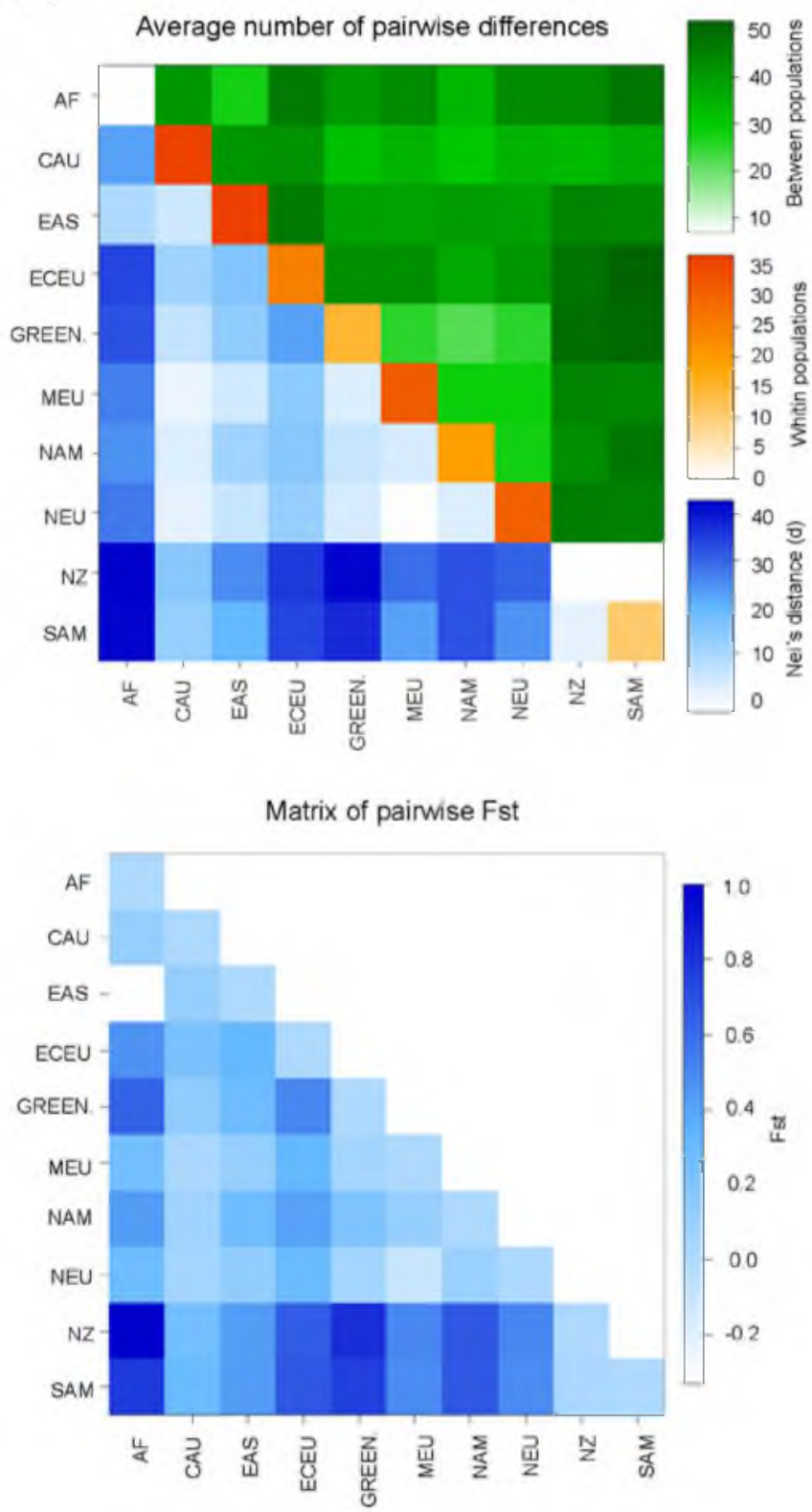

number of pairwise differences within population, and below diagonal is corrected average pairwise difference (Nei's distance). Second row diagrams plot matrices of population pairwise Fsts. A high Fst implies a considerable degree of differentiation among populations. Distance method: pairwise difference. Abbreviations as in Table 2, but also GREEN. = Greenland

the adjacent areas (e.g. Atkinson et al. 2006; Pokryszko et al. 2011). This can be tested, for instance, by examining the level of divergence and differentiation of the areas under study, as we did by performing Fst calculation (Fig. 3; Table 3). A high Fst implies a considerable degree of differentiation among populations. 


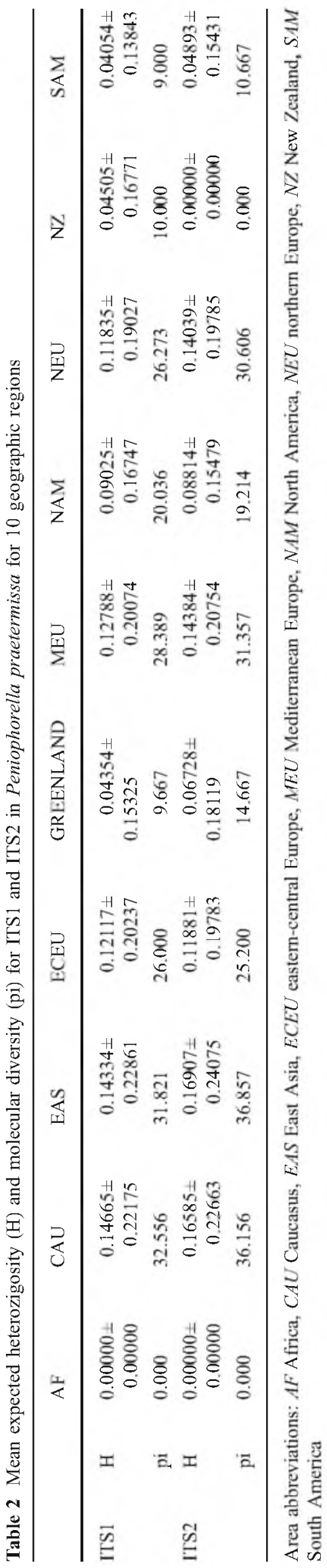

\section{Species endemism and disjunction}

A high level of plant and animal species endemism is well-documented for the Caucasus region (Myers et al. 2000 ; Krever et al. 2001). Some $25 \%$ of its plant species $(1,600$ out of $6,300 \mathrm{spp}$.) are restricted to the region (Myers et al. 2000), and about 10\% of these are woody plants. The situation for fungi has remained less evaluated. Parmasto (1968) briefly pointed out the poverty of aphyllophoroid fungi in the Transcaucasus compared with that of Europe, and considered Oidium curtisii (Berk.) Linder (Botryobasidium curtisii Hallenb.) its only species not present in Europe. The species is, however, now also known from Ukraine. Based on the checklists compiled by us, 12 corticioid species occurring in the Caucasus region are absent in Europe, and 96 species are absent from North America (details available from the corresponding author). Until the year 1981, 23 species were described from the Caucasus region ( $7 \%$ of the total spp., see Suppl. Fig. 2), many of which were later found outside the region, and only two species are currently restricted to the Caucasus (Table 4). Still, these may only be 'endemic by ignorance', i.e., a result of our poor knowledge about their distribution.

For fungi, it seems that factors like host specificity, diversity of substrata and habitats, fungal life form, geographic features and perhaps climate have an effect on the level of endemism (see e.g., Dai and Penttilä 2006; Arnolds 2007; Mueller et al. 2007). In a recent study on global diversity of macrofungi, Mueller et al. (2007) confirmed a general concordance between endemism levels in macrofungi and vascular plants. In woodinhabiting basidiomycetes the situation seems to be different. Here, the level of host specificity is generally low, compared, e.g., with rust fungi (Berndt 2008). The disparity of endemism between plants and corticioid fungi in the Caucasus could also partly be explained by the same fact (see also Arnolds 2007 for comparisons of endemism in fungi and plants). In a study on polypore fungi, Dai and Penttilä (2006) noted low host specificity in NE China, but a high number of endemic polypore species. They linked the high endemism in the NE China with a high diversity of tree species and habitats and lack of Pleistocene glaciations. Such conditions are also present in the Caucasus region, even though forests now cover only about $20 \%$ of the region (Krever et al. 2001). According to Donoghue and Smith (2004), "The generation and retention of particularly great diversity in $\mathrm{E}$ (east) A(sia), compared with the other major Holarctic areas of endemism, has been attributed to topographic and climatic circumstances, and to the greater refuge area available there" (see also references cited therein). A more likely reason for the disparity of plant and corticioid fungal species endemism is, however, the effective spore dispersal in wood-inhabiting corticioid fungi, 


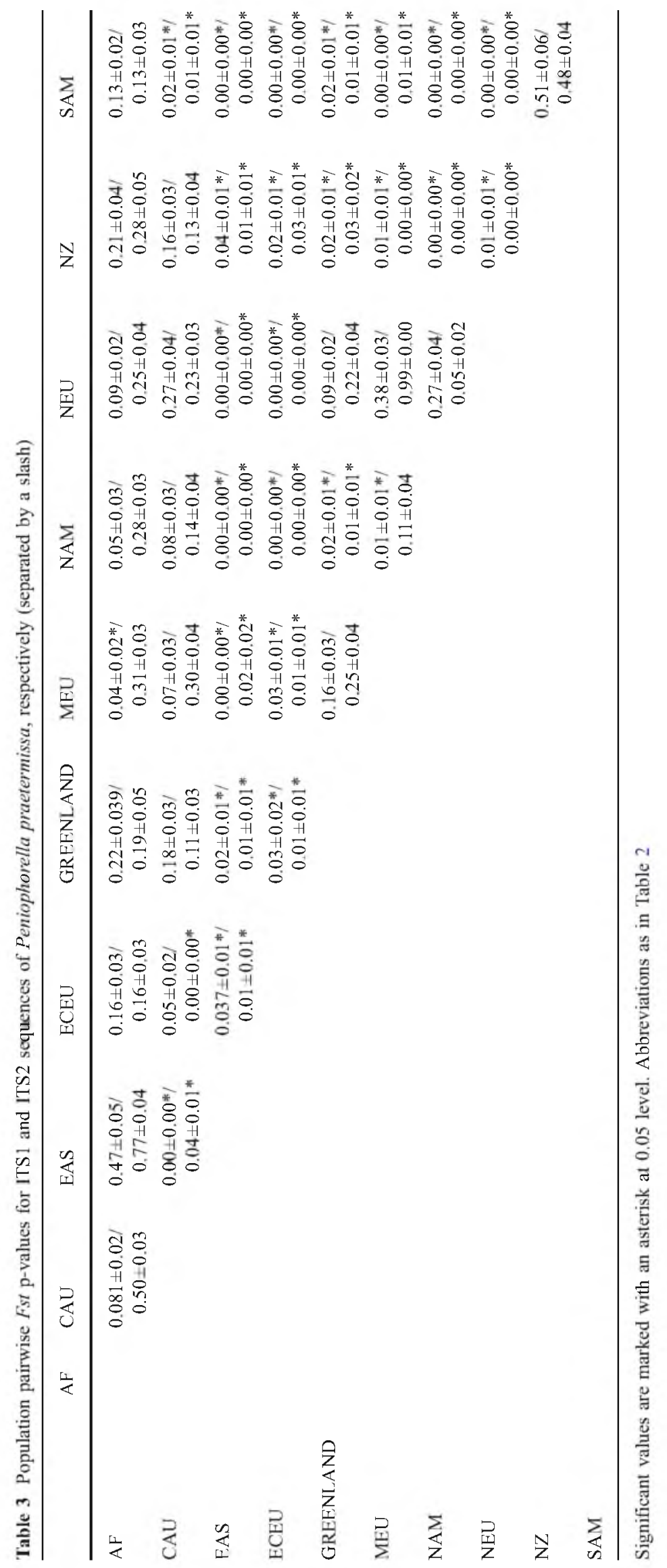


and the fact that the life cycles of basidiomycetes promote the survival of even low density populations (Hallenberg 1995). Accordingly, Mueller et al. (2007) noted low global endemism level for polypores and corticioids, in contrast to sequestrate fungi and Xylariaceae.

In the Caucasus region, 23 putative disjunctive species, i.e. species with broken distribution ranges at a large scale, can be recognized (Table 4). We use the term putative because, as mentioned for the endemics, they may appear to be more widely (and continuously) distributed when more intensive inventories are done. As shown in Table 4, most of these disjunctions are of Caucasus-Mediterranean or Caucasus-northern Europe types, which might be an indication of a connection between the Caucasus and Europe (as shown by similarity tests and genetic diversity results mentioned above). However, such data must be used with caution, because the conspecificity has been inferred based on morphological criteria only (but for $V$. megalospora see Ghobad-Nejhad et al. 2010). A question arises as to whether fungi under a single binomial on different continents represent the same species when examined genetically. The answer is not straightforward because there are examples which either support their divergence or their conspecificity. Moreover, different authors treat the divergent lineages in different ways, either as distinct species, or as belonging within one species continuum. In wood-inhabiting fungi, some examples of genetic divergence leading to cryptic speciation are provided by Nilsson et al. (2003), Kauserud et al. (2006, 2007a), and Moncalvo and Buchanan (2008). They have shown that several cryptic species each show a huge range expansion which must have taken place during the Holocene. On the other hand, Thell and Miao (1999) and Thell et al. (1998 and 2002) provided examples in lichenized fungi, and Ghobad-Nejhad and Dai (2010) for a polypore fungus, where the specimens collected from different continents were shown to belong to the same species. In the Caucasus region, representatives of corticioid species of all continents are found (Suppl. Fig. 2) and at least $15 \%$ of its species can be characterized as 'cosmopolitan' (data not shown).

Several of the tabulated species have scattered point-like distribution, or are 'rare everywhere', and are known only from a few localities. This could perhaps be due to insufficient information on their occurrence, but there are also other disjuncts which do not seem to be due to lack of data. This is shown when a species appears to be common in one continent but rare in another, both being more or less similarly inventoried. Boreostereum radiatum is predominantly distributed in North America, and is known from only a few localities in Eurasia (Table 4). Dendrothele incrustans is mainly known from North America, but is also found in Argentina and the Russian Caucasus (Table 4). The polypore species Cyanotrama rimosa (Murill) Ghobad-
Nejhad is common in western North America and found in a few localities in northern Iran and one locality in Ethiopia, yet is absent from Europe (Ghobad-Nejhad and Dai 2010).

\section{Final remarks}

Fungal biogeography (mycogeography) is still an underdeveloped discipline (Arnolds 2007; Lumbsch et al. 2008). Only a minor portion of the total estimated number of fungal species has been described ( $c a .7 \%$ out of 1.5 million spp.; Hawksworth and Mueller 2008; Kirk et al. 2008) and currently our knowledge of distribution history and geographic structure in fungi is very limited. Compared to plants and animals, for which the fossil record is relatively rich and there is reasonable agreement over the age of major lineages, fossil records are scarce or lacking in saprotrophic fungi. To estimate past events in fungal biogeography, we are therefore confined to the use of indirect methods, and to calibrate our estimates with known events in the general vegetation history. In this study, we have presented the first large-scale comparison of corticioid fungi in the Northern Hemisphere. Such comparisons are still lacking for most groups of fungi.

The Caucasian Pleistocene refugia (Tumajanov 1971) are among the few forested regions in the Northern Hemisphere that remained unglaciated during the Pleistocene (Milne 2006). According to Volodicheva (2002), the Caucasus had favourable Pleistocene habitats compared with much of Europe. There are several examples showing that the Caucasus region has served as an origin of postglacial dispersal and colonization in Europe for some plants (e.g., oak: Atkinson et al. 2006), animals (e.g., chamois: Randi 2006; root vole: Brunhoff et al. 2003; freshwater fishes: Kotlík et al. 2008) and ascomycetous fungi (Letharia: Arnerup et al. 2004). Our results (high similarity between species checklists from the Caucasus and Europe, comparatively high genetic diversity in the Caucasus for an exemplar species, and ITS similarity between the Caucasus and Europe) indicate that this could also be the case in wood-inhabiting basidiomycetes. It is clear that much more sampling is needed in future to explore the fine genetic structure and the actual route of dispersal in the wood mycota inhabiting these refugia. Investigating the history and agents of dispersal, and assessing the human impact on distribution vs. natural distribution of individual species was far beyond the scope of our study.

It must be noted that the scenario of the Caucasus having contributed to the European mycota does not necessarily exclude the role of other areas especially in Russia having served so, but these areas could not be included in this 
Table 4 Putative endemic and putative disjunctive corticioid species in the Caucasus region

\begin{tabular}{|c|c|c|c|}
\hline & Species & Known distribution & Category \\
\hline \multirow[t]{2}{*}{ Putative endemic ${ }^{a}$} & Botryobasidium grandinioides Hallenb. & Iran & \\
\hline & Trechispora granulifera Hallenb. & Iran & \\
\hline \multirow[t]{23}{*}{ Putative disjunct } & Boreostereum radiatum (Peck) Parmasto & $\begin{array}{l}\text { USA, Canada, China, Czech Republic, } \\
\text { Poland, Georgia, Russian Caucasus }\end{array}$ & $\square$ \\
\hline & Corticium erikssonii Jülich & N Europe, Russian Caucasus & $\bullet$ \\
\hline & $\begin{array}{l}\text { Cylindrobasidium eucalypti (M. Dueñas \& Tellería) } \\
\text { Tellería \& Melo }\end{array}$ & France, Iran, Spain & $\bullet$ \\
\hline & Dendrothele incrustans (P.A. Lemke) P.A. Lemke & Argentina, Canada, Russian Caucasus & ! \\
\hline & Galzinia longibasidia Hallenb. & Iran, France & $\bullet$ \\
\hline & $\begin{array}{l}\text { Gloeocystidiellum permixtum (Boidin, Lanq. \& Gilles) } \\
\text { E. Larss. \& K.H. Larss. }\end{array}$ & France, UK, Turkey & $\bullet$ \\
\hline & $\begin{array}{l}\text { Hyphoderma malenconii (Manjón \& G. Moreno) Manjón, } \\
\text { G. Moreno \& Hjortstam }\end{array}$ & Armenia, France, Spain, Morocco, Taiwan & - \\
\hline & Hymenochaete minuscula $\mathrm{G}$. Cunn. & Georgia, Réunion, S America, New Zealand & * \\
\hline & Hyphodontia borealis Kotir. \& Saaren. & Italy, N Europe, Russian Caucasus & - \\
\hline & Hyphodontia halonata J. Erikss. \& Hjortstam & N Europe, Russian Caucasus & $\bullet$ \\
\hline & Intextomyces cystidiatus Hjortstam & Italy, Russian Caucasus & - \\
\hline & Melzericium bourdotii Jülich & France, Sweden, Iran & $\bullet$ \\
\hline & Phanerochaete xerophila Burds. & USA, S America, Korea, Russian Caucasus & $?$ \\
\hline & Phlebia badia (Pat.) Nakasone & Cameroon, Costa Rica, Iran, USA, Vietnam & $?$ \\
\hline & Phlebia caspica Hallenb. & Iran, France & $\bullet$ \\
\hline & Phlebia pulcherrima Parmasto & Altay, Russian Caucasus & o \\
\hline & Sistotrema athelioides Hallenb. & $\begin{array}{l}\text { Argentina, China, Japan, N America, } \\
\text { Switzerland, Turkey }\end{array}$ & $?$ \\
\hline & Sistotrema camshadalicum Parmasto & Iran, Kamchatka & 0 \\
\hline & Sistotrema eximum (H.S. Jacks.) Ryvarden \& Solheim & Russian Caucasus, USA & - \\
\hline & Steccherinum gilvum Maas Geest. & Iran, Japan & 0 \\
\hline & Trechispora subhelvetica (Parmasto) Liberta & Armenia, Norway & - \\
\hline & Tubulicrinis incrassatus Hallenb. & Iran, Italy, Spain & $\bullet$ \\
\hline & Vuilleminia megalospora Bres. & Iran, Italy, France & $\bullet$ \\
\hline
\end{tabular}

Geographic names in bold are places where the species is more commonly found. Categories: Caucasus-Mediterranean/N Europe $(\bullet)$, AmericasCaucasus (®), Northern Hemisphere (๑), Caucasus-East Asia (๑), Caucasus-Southern Hemisphere (*), Eurasia ( $\bullet$ ), undefined (?). Iran and Turkey refer to the Caucasian parts of these countries (see Ghobad-Nejhad et al. 2009)

${ }^{a}$ Species recently described from the Caucasus region (after 1981) are not taken into account

study due to the lack of information. Accordingly, due to the lack of updated and satisfactory corticioid species lists from several parts of Asia, the similarity patterns presented here remain inconclusive. While we tried to use the most updated information about the occurrence of corticioids in the areas analysed here, it would be ideal to reiterate the analyses with information gained from future biodiversity inventories. Our inference about the 'source area' using the commonly applied measures (genetic diversity and the level of differentiation) needs to be supplemented in future by taking additional and more sophisticated models as well as other genetic markers into consideration, to further explore the hypotheses presented here. Moreover, the history of diversity reclamation in Europe and contrasting the magnitude to which this was derived from the Caucasus, relative to other areas, is still an open question.
Acknowledgements We are grateful to Morten Christiansen (Denmark), Gurpaul S. Dhingra (India), Sergio Pérez Gorjón (Argentina), Annarosa Bernicchia (Italy), and Sheng-Hua Wu (Taiwan) for kindly sending us their unpublished checklists. Erast Parmasto and Ilmi Parmasto (Estonia) are warmly thanked for arranging several valuable loans from TAA herbarium. We thank Peter Roberts (England) for his advice on the English. Thanks are due to Bernard Duhem (France) for identifying Phlebia margaritae from Iran. This study was supported by Göteborg Stenholm Foundation, Societas pro Fauna et Flora Fennica, and University of Helsinki Chancellor Grant.

\section{References}

Akulov AYu, Usichenko AS, Leontyev DV, Yurchenko EO, Prydiuk MP (2003) Annotated checklist of aphyllophoroid fungi of Ukraine. Mycena 2:1-75 
Andreasen M, Hallenberg N (2009) A taxonomic survey of the Peniophoraceae. Synop Fungorum 26:56-119

Arnerup J, Högberg N, Thor G (2004) Phylogenetic analysis of multiple loci reveal the population structure within Letharia in the Caucasus and Morocco. Mycol Res 108:311-316

Arnolds EJM (2007) Biogeography and conservation. In: Wicklow DT, Söderström B (eds) The mycota, vol IV. Environmental and microbial relationships. Springer, Berlin, pp 115-131

Atkinson RJ, Rokas A, Stone GN (2006) Longitudinal patterns in species richness and genetic diversity in European oaks and oak gallwasps. In: Weiss S, Ferrand N (eds) Phylogeography of Southern European refugia. Evolutionary perspectives on the origins and conservation of European biodiversity. Springer, Netherlands, pp 127-151

Berndt R (2008) The rust mycobiota of southern Africa: species richness, composition and affinities. Mycol Res 112:463-471

Bernicchia A, Gorjón SP (2010) Fungi Europaei 12 - Corticiaceae s.l. Edizioni Candusso, Italy

Breitenbach J, Kränzlin F (1986) Fungi of Switzerland, vol 2, nongilled Fungi. Verlag Mykologia, Luzern

Brunhoff C, Galbreath KE, Fedorov VB, Cook JA, Jaarola M (2003) Holarctic phylogeography of the root vole (Microtus oecono$m u s$ ): implications for late Quaternary biogeography of high latitudes. Mol Ecol 12:957-968

Carlsen T, Engh IB, Decock C, Rajchenberg M, Kauserud H (2011) Multiple cryptic species with divergent substrate affinities in the Serpula himantioides species complex. Fungal Biol 115:54-61

Cheddadi R, Beaulieu JL, de Jouzel J, Andrieu-Ponel V, Laurent JM, Reille M, Raynaud D, Bar-Hen A (2005) Similarity of vegetation dynamics during interglacial periods. Proc Natl Acad Sci U S A 102:13939-13943

Dai YC (2010) A revised checklist of corticioid and hydnoid fungi in China for 2010. Mycoscience 52:69-79

Dai YC, Penttilā R (2006) Polypore diversity of fenglin nature reserve, northeastern China. Ann Bot Fenn 43:81-96

Dai YC, Wei YL, Zhang XQ (2004) An annotated checklist of nonporoid Aphyllophorales in China. Ann Bot Fenn 41:233-247

Dämon W (2001) Die corticioiden Basidienpilze des Bundeslandes Salzburg (Osterreich), Floristik, Lebensraume und Substratokologie. Bibliotheca Mycologica 189. J Cramer, Lehre

Davis SD, Heywood VH, Hamilton AC (eds) (1995) Centers of plant diversity, a guide strategy for their conservation, vol 2. Australia, Asia, and the Pacific. IUCN Publications Unit, Cambridge

Denchev CM, Assyov B (2010) Checklist of the larger basidiomycetes in Bulgaria. Mycotaxon 111:279-282 (summary), www.my cotaxon.com/resources/checklists/denchev-v111-checklist.pdf (PDF)

R Development Core Team (2008) R, a language and environment for statistical computing. R Foundation for Statistical Computing, Vienna, Austria. http:/www.R-project.org. Accessed December 2010

Donoghue MJ, Smith SA (2004) Patterns in the assembly of temperate forests around the Northern Hemisphere. Philos Trans R Soc B 359:1633-1644

Excoffier L, Lischer HEL (2010) Arlequin suite ver. 3.5: A new series of programs to perform population genetics analyses under Linux and Windows. Mol Ecol Resour 10:564-567

Feuerer T, Hawksworth DL (2007) Biodiversity of lichens, including a world-wide analysis of checklist data based on Takhtajan's floristic regions. Biodivers Conserv 16:85-98

Geml J, Laursen GA, Taylor DL (2008) Molecular phylogenetic diversity assessment of arctic and boreal Agaricus taxa. Mycologia 100:577-589

Ghobad-Nejhad M (2011) Wood-inhabiting basidiomycetes in the Caucasus region - systematics and biogeography. Publications in
Botany from the University of Helsinki. No 40. Yliopistopaino, Helsinki

Ghobad-Nejhad M, Dai YC (2010) Diplomitoporus rimosus is found in Asia and belongs to the Hymenochaetales. Mycologia 102:1510-1517

Ghobad-Nejhad M, Hallenberg N, Parmasto E, Kotiranta H (2009) A first annotated checklist of corticioid and polypore basidiomycetes of the Caucasus region. Mycol Balc 6:123-168

Ghobad-Nejhad M, Nilsson RH, Hallenberg N (2010) Phylogeny and taxonomy of the genus Vuilleminia (Basidiomycota) based on molecular and morphological evidence, with new insights into Corticiales. Taxon 59:1519-1534

Ginns JH, Lefebvre MNL (1993) Lignicolous corticioid fungi (Basidiomycota) of North America, systematics, distribution, and ecology. Mycol Mem 19:1-247

Hallenberg N (1995) Dispersal abilities and distributional patterns in Aphyllophorales, with emphasis on corticoid fungi. Symb Bot Ups 30:95-100

Hallenberg N, Nilsson RH, Antonelli A, Wu SH, Maekawa N, Nordén B (2007) The Peniophorella praetermissa species complex (Basidiomycota). Mycol Res 111:1366-1376

Hansen L, Knudsen H (eds) (1997) Nordic macromycetes, vol 3, heterobasidioid, aphyllophoroid and gasteromycetoid basidiomycetes. Nordsvamp, Copenhagen

Hawksworth DL, Mueller GM (2008) Fungal communities, their diversity and distribution. In: Dighton $\mathrm{J}$, White $\mathrm{J}$, Oudemans $\mathrm{P}$ (eds) The fungal community, its organization and role in the ecosystem. CRC Taylor and Francis, New York, pp 27-37

Hewitt GM (1999) Post-glacial re-colonization of European biota Biol J Linn Soc 68:87-112

Hewitt GM (2004) The structure of biodiversity, insights from molecular biodiversity. Front Zool 1:4

Hjortstam K, Ryvarden L (1984) Some new and noteworthy Basidiomycetes (Aphyllophorales) from Nepal. Mycotaxon $20: 133-151$

Hjortstam K, Roberts PJ, Spooner BM (1998) Corticioid fungi from Brunei Darussalam. Kew Bull 53:805-827

Huntley B, Webb T III (1988) Vegetation history. Handbook of vegetation science, part 7 . Dordrecht, Kluwer, Netherlands

Katoh K, Toh H (2008) Recent developments in the MAFFT multiple sequence alignment program. Brief Bioinforma 9:286-298

Kauserud H, Stensrud $\varnothing$, Decock C, Shalchian-Tabrizi K, Schumacher T (2006) Multiple gene genealogies and AFLPs suggest cryptic speciation and long-distance dispersal in the basidiomycete Serpula himantioides (Boletales). Mol Ecol 15:421-431

Kauserud H, Svegârden IB, Decock C, Hallenberg N (2007a) Hybridization among cryptic species of the cellar fungus Coniophora puteana (Basidiomycota). Mol Ecol 16:389-399

Kauserud H, Svegården IB, Saetre GP, Knudsen H, Stensrud Ø, Schmidt O, Doi S, Sugiyama T, Högberg N (2007b) Asian origin and rapid global spread of the destructive dry rot fungus Serpula lacrymans. Mol Ecol 16:3350-3360

Kirk PM, Cannon PF, Minter DW, Stalpers JA (2008) Dictionary of the fungi. CABI, Wallingford

Kotiranta H, Saarenoksa R, Kytôvuori I (2009) Aphyllophoroid fungi of Finland, a checklist with ecology, distribution, and threat categories. Norrlinia 19:1-223

Kotlík P, Marková S, Choleva L, Bogutskaya NG, Ekmekçi FG, Ivanova PP (2008) Divergence with gene flow between PontoCaspian refugia in an anadromous cyprinid Rutilus frisii revealed by multiple gene phylogeography. Mol Ecol 17:1076-1088

Krever V, Zazanashvili N, Jungius H, Williams L, Petelin D (2001) Biodiversity of the Caucasus ecoregion. World Wide Fund for Nature, Moscow 
Langer E (1994) Die Gattung Hyphodontia John Eriksson. Bibliotheca Mycologica 154. J Cramer, Lehre

Lee JS, Jung HS (2005) List of recorded Korean Aphyllophorales. Korean J Mycol 33:38-53

Lee JS, Jung HS (2006) Taxonomic study on Korean Aphyllophorales 5: on some unrecorded genera and species. Mycobiology $34: 166-175$

Lee JS, Kim KM, Jung HS (2002) The Aphyllophorales of the Kyeryoungsan National Park. Mycobiology 30:133-138

Legon NW, Henrici A, Roberts PJ, Spooner BM, Watling R (2005) Checklist of the British and Irish Basidiomycota. Royal Botanic Gardens, Kew

Lim YW, Lee JS, Kim KM, Jung HS (2005) Wood-rotting fungal flora of Kanghwa Island. Mycobiology 33:167-172

Lomolino MV, Riddle BR, Brown JH (2006) Biogeography, 3rd edn. Sinauer Associates, Sunderland

Lumbsch HT, Buchanan PK, May TW, Mueller GM (2008) Phylogeography and biogeography of fungi. Mycol Res 112:423-424

Maurer W, Dämon W, Forstinger H, Petrini L, Scheuer C (2009) Holzabbauende Pilze der Steiermark, V. Joannea Bot 7:9-34

Milne RI (2006) Northern Hemisphere plant disjunctions: a window on tertiary land bridges and climate change? Ann Bot 98:465472

Moncalvo JM, Buchanan PK (2008) Molecular evidence for long distance dispersal across the Southern Hemisphere in the Ganoderma applanatum-australe species complex (Basidiomycota). Mycol Res 112:425-436

Mueller GM, Wu QX, Huang YQ, Guo SY, Aldana-Gomez R, Vilgalys R (2001) Assessing biogeographic relationships between North American and Chinese macrofungi. J Biogeogr 28:271-281

Mueller GM, Schmit JP, Leacock PR, Buyck B, Cifuentes J, Desjardin DE, Halling RE, Hjortstam $\mathrm{K}$, Iturriaga $\mathrm{T}$, Larsson $\mathrm{KH}$, Lodge DJ, May TW, Minter D, Rajchenberg M, Redhead SA, Ryvarden L, Trappe JM, Watling R, Wu Q (2007) Global diversity and distribution of macrofungi. Biodivers Conserv 16:37-48

Myers N, Mittermeier RA, Mittermeier CG, da Fonseca GAB, Kent J (2000) Biodiversity hotspots for conservation priorities. Nature 403:853-858

Natarajan K, Kolandavelu K (1998) Resupinate Aphyllophorales of Tamil Nadu, India. Centre for advanced study in Botany, University of Madras

Nilsson RH, Hallenberg N, Nordén B, Maekawa N, Wu SH (2003) Phylogeography of Hyphoderma setigerum (Basidiomycota) in the Northern Hemisphere. Mycol Res 107:645-652

Nilsson RH, Kristiansson E, Ryberg M, Hallenberg N, Larsson KH (2008) Intraspecific ITS variability in the kingdom fungi as expressed in the international sequence databases and its implications for molecular species identification. Evol Bioinforma Online 4:193-201

Nún̂ez M, Stokland J (2000) Biogeographical affinities of East Asian polypores. Karstenia 40:123-128

Parmasto E (1968) The genus Oidium Fr. (deuteromycetes) in the Transcaucasus. Tartu Riiklik Ülik Toim 21:85-93 (In Russian)

Parmasto E (1986) Preliminary list of Vietnamese Aphyllophorales and Polyporaceae s. str. Scr Mycol 14:1-88

Parmasto E, Nilsson H, Larsson KH (2004) Cortbase v2 - extensive updates of a nomenclatural database for corticioid fungi (hymenomycetes). Phyloinformatics 5:1-7

Pokryszko BM, Cameron RAD, Mumladze L, Tarkhnishvili D (2011) Forest snail faunas from Georgian Transcaucasia: patterns of diversity in a Pleistocene refugium. Biol J Linn Soc 102:239 250
Randi E (2006) Phylogeography of South European mammals. In: Weiss S, Ferrand $N$ (eds) Phylogeography of Southern European Refugia. Evolutionary perspectives on the origins and conservation of European biodiversity. Springer, Netherlands, pp 101-126

Rattan SS (1977) The resupinate Aphyllophorales of NW Himalayas Bibliotheca Mycologica 60. J Cramer, Lehre

Ray N, Adams JM (2001) A GIS-based vegetation map of the world at the Last Glacial Maximum (25,000-15,000 BP). Internet Archaeol 11:1-44

Robba E, Negri MP, Di Geronimo I, Chaimanee N, Sanfilippo R (2005) Paleoecological interpretation of a Holocene sand body in the coastal area of Phetchaburi, Gulf of Thailand. Annali dell'Università degli Studi di Ferrara. Museologia Scientifica e Naturalistica, volume speciale, pp 99-107

Ryvarden L (2010) Stereoid fungi of America. Synop Fungorum 28:1-208

Ryvarden L, Stokland J, Larsson KH (2003) A critical checklist of corticoid and poroid fungi of Norway. Synop Fungorum 17:3-79

Schils T (2006) The tripartite biogeographical index: a new tool for quantifying spatio-temporal differences in distribution patterns. $\mathrm{J}$ Biogeogr 33:560-572

Schils T, Wilson SC (2006) Temperature threshold as a biogeographic barrier in northern Indian Ocean macroalgae. J Phycol 42:749756

Svenning J-C, Normand S, Kageyama M (2008) Glacial refugia of temperate trees in Europe: insights from species distribution modelling. J Ecol 96:1117-1127

Taberlet P, Fumagalli L, Wust-Saucy AG, Cosson JF (1998) Comparative phylogeography and postglacial colonization routes in Europe. Mol Ecol 7:453-464

Tarasov PE, Volkova VS, Webb T III, Guiot J, Andreev AA, Bezusko LG, Bezusko TV, Bykova GV, Dorofeyuk NI, Kvavadze EV, Osipova IM, Panova NK, Sevastyanov DV (2000) Last glacial maximum biomes reconstructed from pollen and plant macrofossil data from northem Eurasia. J Biogeogr 27:609-620

Thell A, Miao V (1999) Phylogenetic analysis of ITS and group I intron sequences from European and American samples of cetrarioid lichens. Ann Bot Fenn 35:275-286

Thell A, Berbee M, Miao V (1998) Phylogeny within the genus Platismatia based on rDNA ITS sequences (lichenized Ascomycota). Cryptogm Bryol - Lichénol 19:307-319

Tulloss RE (1997) Assessment of similarity indices for undesirable properties and a new tripartite similarity index based on cost functions. In: Palm ME, Chapela $\mathrm{IH}$ (eds) Mycology in sustainable development: expanding concepts, vanishing borders. Parkway, Boone, pp 122-143

Tulloss RE (2005) Amanita, distribution in the Americas with comparison to eastern and southern Asia and notes on spore character variation with latitude and ecology. Mycotaxon 93:189-231

Tulloss RE, Tulloss DC (2004) An on-line tripartite similarity calculator. Inoculum 55:1-4

Tumajanov II (1971) Changes of the Great Caucasus forest vegetation during the Pleistocene and Holocene. In: Davis $\mathrm{PH}$, Harper PC, Hedge IC (eds) Plant life of Southwest Asia. Botanical Society of Edinburgh, Edinburgh, pp 73-87

Villesen P (2007) FaBox: an online toolbox for fasta sequences. Mol Ecol Notes 7:965-968

Volodicheva N (2002) The Caucasus. In: Shahgedanova M (ed) The physical geography of northern Eurasia. Oxford University Press, Oxford, pp 350-376

Weiss S, Ferrand N (2006) Phylogeography of Southern European refugia. Evolutionary perspectives on the origins and conservation of European biodiversity. Springer, Netherlands 
Winemiller KO, Lopez-Fernandez $\mathrm{H}$, Taphorn DC, Nico L, Barbarino A (2008) Fish assemblages of the Casiquiare river, a corridor and zoogeographic filter for dispersal between the Orinoco and Amazon basins. J Biogeogr 35:1551-1563

Wirtz N, Printzen C, Lumbsch HT (2008) The delimitation of Antarctic and bipolar species of neuropogonoid Usnea (Ascomycota, Lecanorales): a cohesion approach of species recognition for the Usnea perpusilla complex. Mycol Res 112:472-84

Yap IV, Nelson RJ (1996) Winboot: a program for performing bootstrap analysis of binary data to determine the confi- dence limits of UPGMA-based dendrograms. IRRI Discuss Pap Ser 14

Yurchenko EO (2010) The genus Peniophora (Basidiomycota) of central and eastern Europe, morphology, taxonomy, ecology, distribution. Belorusskaya nauka, Minsk

Zhang ML, Uhink CH, Kadereit JW (2007) The phylogeny and biogeography of Epimedium/Vancouveria (Berberidaceae): Western North American-East Asian disjunctions, the origin of European mountain plant taxa, and East Asian species diversity. Syst Bot 32:81-92 
Supplementary Table 1 Published documents and sources used in assembling checklists of corticioids and the genera Hyphodontia, Peniophora, and Phlebia, as well as calculated T values. Numbers in square brackets are $a, b$, and c, respectively $(a=$ the number of entries common to both lists, $b=$ the number of entries in the first list that are not in the second, and $c=$ the number of entries in the second list that are not in the first). Area abbreviations as in Fig. 1

\begin{tabular}{|c|c|c|c|c|c|}
\hline \multirow[b]{2}{*}{ Area } & \multirow[b]{2}{*}{ Source } & \multicolumn{4}{|c|}{$\mathrm{T}$ index } \\
\hline & & Hyphodontia & Peniophora & Phlebia & Total corticioids \\
\hline $\mathrm{CAU}$ & 10 & - & - & - & - \\
\hline CAU-ECEU & $1,2,3,7,8,22,29$ & $0.70[27,1,7]$ & $0.89[24,0,2]$ & $0.38[22,4,18]$ & $0.41[344,34,258]$ \\
\hline CAU-NEU & $2,12,15,19,26$ & $0.67[28,0,9]$ & $0.68[20,4,5]$ & $0.38[21,5,17]$ & $0.36[318,60,282]$ \\
\hline CAU-MEU & 2 & $0.65[27,1,9]$ & $0.65[22,2,7]$ & $0.32[20,6,20]$ & $0.36[339,39,310]$ \\
\hline CAU-EAS & $\begin{array}{l}5,6,13,16,17,18 \\
20,21,24,28\end{array}$ & $0.21[22,6,35]$ & $0.25[13,11,15]$ & $0.25[12,14,11]$ & $\begin{array}{l}0.21[187,193, \\
251]\end{array}$ \\
\hline CAU-WNAM & $11,27,30$ & $0.58[20,8,3]$ & $0.43[15,9,7]$ & $0.48[18,8,9]$ & $\begin{array}{l}0.28[236,144, \\
247]\end{array}$ \\
\hline CAU-ENAM & $11,27,30$ & $0.55[20,8,7]$ & $0.42[16,8,10]$ & $0.32[18,8,17]$ & $\begin{array}{l}0.25[258,122, \\
329]\end{array}$ \\
\hline CAU-IND & $4,9,14,23,25$ & $0.38[16,12,7]$ & $0.16[8,16,3]$ & $0.17[10,16,14]$ & $\begin{array}{l}0.19[150,230 \\
126]\end{array}$ \\
\hline \multicolumn{6}{|c|}{$\begin{array}{l}\text { 1: Akulov AYu, Usichenko AS, Leontyev DV, Yurchenko EO, Prydiuk MP (2003) Annotated checklist of aphyllophoroid fungi of Ukraine. } \\
\text { Mycena 2:1-75 }\end{array}$} \\
\hline \multicolumn{6}{|c|}{$\begin{array}{l}\text { 5: Dai YC, Wei YL, Zhang XQ (2004) An annotated checklist of non-poroid Aphyllophorales in China. Ann Bot Fenn } 41: 233-247 \\
\text { 6: Dai YC (2010) A revised checklist of corticioid and hydnoid fungi in China for 2010. Mycoscience. doi: 10.1007/s10267-010-0068-1 } \\
\text { 7: Dämon W (2001) Die corticioiden Basidienpilze des Bundeslandes Salzburg (Österreich), Floristik, Lebensraume und Substratokologie. } \\
\text { Bibliotheca Mycologica 189. I Cramer, Lehre, West Germany }\end{array}$} \\
\hline \multicolumn{6}{|c|}{$\begin{array}{l}\text { 8: Denchev CM, Assyov B (2010) Checklist of the larger basidiomycetes in Bulgaria. Mycotaxon 111:279-282 (summary), } \\
\text { www.mycotaxon.com/resources/checklists/denchev-v111-checklist.pdf (PDF) }\end{array}$} \\
\hline \multicolumn{6}{|c|}{ 9: Dhingra G (pers. comm.) } \\
\hline \multicolumn{6}{|c|}{$\begin{array}{l}\text { 10: Ghobad-Nejhad M, Hallenberg N, Parmasto E, Kotiranta H (2009) A first annotated checklist of corticioid and polypore basidiomycetes } \\
\text { of the Caucasus region. Mycol Balc 6:123-168; Also additional updates }\end{array}$} \\
\hline \multicolumn{6}{|c|}{$\begin{array}{l}\text { 11: Ginns JH, Lefebvre MNL (1993) Lignicolous corticioid fungi (Basidiomycota) of North America, systematics, distribution, and ecology. } \\
\text { Mycol Mem 19:1-247 }\end{array}$} \\
\hline \multicolumn{6}{|c|}{$\begin{array}{l}\text { 12: Hansen L, Knudsen H (eds) (1997) Nordic macromycetes, vol 3, heterobasidioid, aphyllophoroid and gasteromycetoid basidiomycetes. } \\
\text { Nordsvamp, Copenhagen }\end{array}$} \\
\hline \multicolumn{6}{|c|}{ 13: Hjortstam K, Roberts PJ, Spooner BM (1998) Corticioid fungi from Brunei Darussalam. Kew Bull 53:805-827 } \\
\hline \multicolumn{6}{|c|}{ 14: Hjortstam K, Ryvarden L (1984) Some new and noteworthy Basidiomycetes (Aphyllophorales) from Nepal. Mycotaxon 20:133-151 } \\
\hline \multicolumn{6}{|c|}{$\begin{array}{l}\text { 15: Kotiranta H, Saarenoksa R, Kytövuori I (2009) Aphyllophoroid fungi of Finland, a checklist with ecology, distribution, and threat } \\
\text { categories. Norrlinia 19:1-223 }\end{array}$} \\
\hline \multicolumn{6}{|c|}{ 16: Lee JS, Kim KM, Jung HS (2002) The Aphyllophorales of the Kyeryoungsan National Park. Mycobiology 30:133-138 } \\
\hline \multicolumn{6}{|c|}{$\begin{array}{l}\text { 18: Lee, JS, Jung HS (2006) Taxonomic study on Korean Aphyllophorales 5: on some unrecorded genera and species Mycobiology 34: } 166- \\
175\end{array}$} \\
\hline \multicolumn{6}{|c|}{$\begin{array}{l}\text { 19: Legon NW, Henrici A, Roberts PI, Spooner BM, Watling R (2005) Checklist of the British and Irish Basidiomycota. Royal Botanic } \\
\text { Gardens, Kew }\end{array}$} \\
\hline \multicolumn{6}{|c|}{ 20: Lim YW, Lee JS, Kim KM, Jung HS (2005) Wood-rotting fungal flora of Kanghwa Island. Mycobiology 33:167-172 } \\
\hline \multicolumn{6}{|c|}{ 21: Maekawa N (several papers on corticioids of Japan) } \\
\hline \multirow{2}{*}{\multicolumn{6}{|c|}{$\begin{array}{l}\text { 22: Maurer W, Dämon W, Forstinger H, Petrini L, Scheuer C (2009) Holzabbauende Pilze der Steiermark, V. Joannea Bot 7:9-34 } \\
\text { 23: Natarajan K, Kolandavelu K (1998) Resupinate Aphyllophorales of Tamil Nadu, India. Centre for advanced study in Botany, University } \\
\text { of Madras }\end{array}$}} \\
\hline & & & & & \\
\hline \multicolumn{6}{|c|}{ 24: Parmasto E (1986) Preliminary list of Vietnamese Aphyllophorales and Polyporaceae s. str. Scr Mycol 14:1-88 } \\
\hline \multirow{4}{*}{\multicolumn{6}{|c|}{$\begin{array}{l}\text { 25: Rattan SS (1977) The resupinate Aphyllophorales of NW Himalayas. Bibliotheca Mycologica } 60 \text {. J Cramer, Le } \\
\text { 26: Ryvarden L, Stokland J, Larsson KH (2003) A critical checklist of corticoid and poroid fungi of Norway. Synol } \\
\text { 27: Ryvarden L (2010) Stereoid fungi of America. Synop Fungorum 28: 1-208 } \\
\text { 28: Wu SH (pers. comm.) }\end{array}$}} \\
\hline & & & & & \\
\hline & & & & & \\
\hline & & & & & \\
\hline \multicolumn{6}{|c|}{ 29: Yurchenko EO (2010) The genus Peniophora (Basidiomycota) of central ar } \\
\hline
\end{tabular}

Supplementary Table 2 Groups selected for comparisons of Tripartite similarity index and for drawing dendrograms. $\mathrm{n}=$ number of species

\begin{tabular}{|c|c|c|}
\hline Taxon & As treated in & Ecological guild \\
\hline Hyphodontia $(\mathrm{n}=73)$ & 3 & \\
\hline Peniophora $(\mathrm{n}=56)$ & 1,5, Cortbase v. 2.1 & 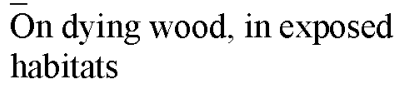 \\
\hline Phlebia $(\mathrm{n}=77)$ & 4, Cortbase v. 2.1 & $\begin{array}{l}\text { On decayed wood, in moist } \\
\text { habitats }\end{array}$ \\
\hline Total corticioids $(n=1293)$ & 2 & Diverse \\
\hline \multicolumn{3}{|c|}{$\begin{array}{l}\text { 1: Andreasen M, Hallenberg N (2009) A taxonomic survey of the Peniophoraceae. Synop Fungorum 26:56-119 } \\
\text { 2: Ghobad-Nejhad M, Hallenberg N, Parmasto E, Kotiranta H (2009) A first annotated checklist of corticioid and polypore basidiomycetes of } \\
\text { the Caucasus region. Mycol Balc 6:123-168 } \\
\text { 3: Langer E (1994) Die Gattung Hyphodontia John Eriksson. Bibliotheca Mycologica 154. J Cramer, Lehre, West Germany } \\
\text { 4: Several individual papers by Karen Nakasone } \\
\text { 5: Yurchenko EO (2010) The genus Peniophora (Basidiomycota) of central and eastern Europe, morphology, taxonomy, ecology, } \\
\quad \text { distribution. Belorusskaya nauka, Minsk }\end{array}$} \\
\hline
\end{tabular}


Supplementary Table 3 Tripartite similarity values obtained from comparisons of total corticioids of the Caucasus, Europe, eastern N America, western N America, East Asia, and India. Numbers in square brackets are $a, b$, and $c$, respectively $(a=$ the number of entries common to both lists, $b=$ the number of entries in the first list that are not in the second, and $c=$ the number of entries in the second list that are not in the first). Area abbreviations are as in Fig. 1. For EAS in this Table, only China could be included. The number of species from each area for calculations on total corticioids is as the following: $\mathrm{CAU}=380, \mathrm{ECEU}=602, \mathrm{NEU}=600, \mathrm{MEU}=649$, $\mathrm{WNAM}=473, \mathrm{ENAM}=587, \mathrm{EAS}=438, \mathrm{IND}=276$, Europe $=781$

\begin{tabular}{ll}
\hline & $T$ index \\
\hline CAU-ENAM & $0.25[258,122,329]$ \\
CAU-Europe & $0.31[367,12,416]$ \\
CAU-IND & $0.19[150,230,126]$ \\
CAU-WNAM & $0.28[236,144,247]$ \\
EAS-CAU & $0.21[187,193,251]$ \\
EAS-ENAM & $0.21[240,345,195]$ \\
EAS- Europe & $0.14[253,528,182]$ \\
EAS-IND & $0.15[147,288,130]$ \\
EAS-WNAM & $0.22[209,270,226]$ \\
ENAM- Europe & $0.28[374,407,211]$ \\
ENAM-IND & $0.11[164,421,113]$ \\
Europe-IND & $0.08[184,597,93]$ \\
WNAM-ENAM & $0.41[346,133,239]$ \\
WNAM- Europe & $0.24[334,447,145]$ \\
WNAM-IND & $0.13[148,331,129]$ \\
\hline
\end{tabular}

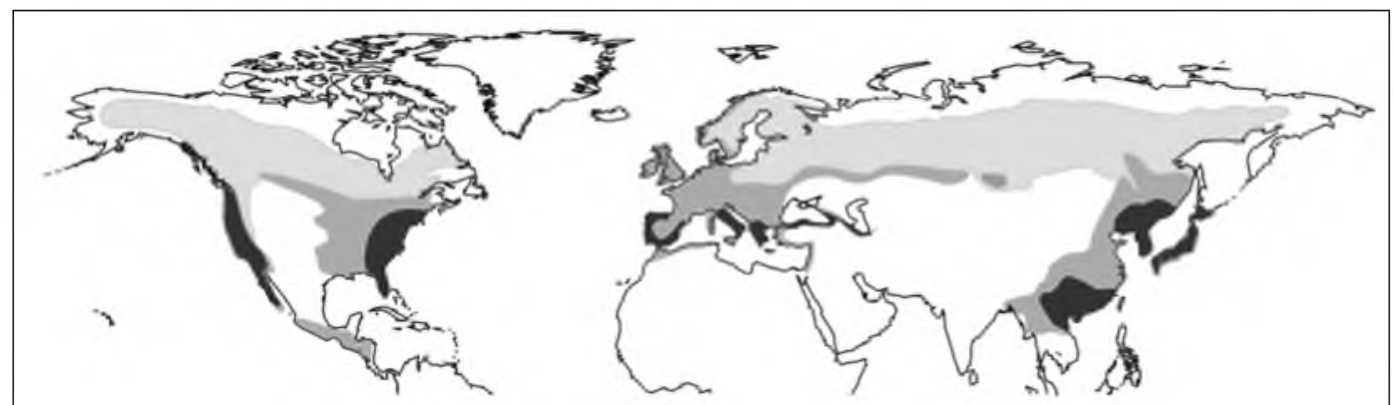

Supplementary Fig. 1 Northern Hemisphere Pleistocene glacial refugia (black), and the present temperate (dark grey) and boreal (light grey) forests. Black areas mainly after Milne (2006), Taberlet et al. (1998), and Tarasov et al. (2000). Grey areas after Lomolino et al. (2006). See also Svenning et al. (2008) who propose larger refugia areas in Europe esp. for a number of boreal plant species

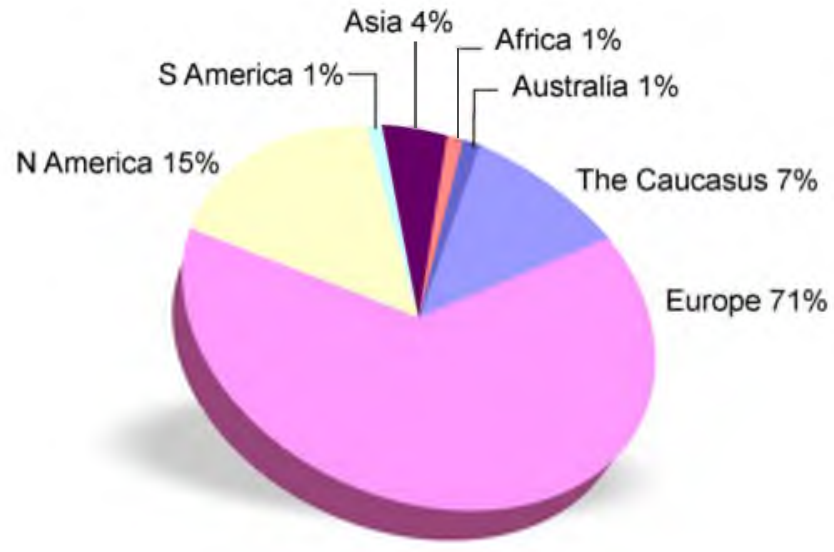

Supplementary Fig. 2 Pie chart representing the percentage of the corticioids occurring in the Caucasus region but originally described from places other than this region. Only seven percent of the corticioids of the Caucasus were originally described from this region, while the majority of the species (71\%) have been described from Europe. 